\title{
AC 2008-259: DEVELOPMENT OF A TEAM INTERACTION OBSERVATION PROTOCOL AND A SELF-EFFICACY SURVEY USING SOCIAL COGNITIVE THEORY AS A FRAMEWORK
}

\section{Senay Yasar Purzer, Arizona State University}

Senay Yasar-Purzer is a Ph.D. candidate in Science Education, Department of Curriculum and Instruction at Arizona State University (ASU). She currently works as a graduate research associate in the Communication in Science Inquiry Project, an NSF-funded teacher professional development program. She earned her master's degree in Science Education at ASU. She has a BS degree in Physics Education and is currently pursuing another B.S.E degree with a concentration in mechanical systems. In 2007, she received the Dean's Excellence award in graduate research from the Mary Lou Fulton School of Education. Her creative research focuses on team learning and the role of self-efficacy on student achievement.

\section{Dale Baker, Arizona State University}

Dale R. Baker is a Professor of Science Education in the Department of Curriculum and Instruction at Arizona State University and was the Co-Editor of The Journal of Research in Science Teaching. She teaches courses in science curricula, teaching and learning, and assessment courses with an emphasis on constructivist theory and issues of equity. Her research focuses on issues of gender, science, and science teaching. She has won two awards for her research in these areas. She was elected a fellow of the American Association for the Advancement of Science in 2004.

\section{Chell Roberts, Arizona State University}

Chell A. Roberts is an associate professor and Director of Engineering at Arizona State University Polytechnic. He received his Ph.D. in Industrial Engineering and Operations Research from Virginia Tech in 1991. He has a MS in Industrial Engineering and a BA in Mathematics from the University of Utah. He is a member of the board of directors for the Society for Computer Simulation International and has been actively involved in developing undergraduate engineering design curriculum. (C) American Society for Engineering Education, 2007

\section{Stephen Krause, Arizona State University}

Stephen J. Krause is Professor in the School of Materials in the Fulton School of Engineering at Arizona State University. His teaching responsibilities are in the areas of bridging engineering and education, design and selection of materials, general materials engineering, polymer science, and characterization of materials. His research interests are in innovative education in engineering and K-12 engineering outreach. He has co-developed a Materials Concept Inventory for assessing fundamental knowledge of students in introductory materials engineering classes. Most recently, he has been working on Project Pathways, an NSF supported Math Science Partnership, in developing modules for a course on Connecting Mathematics with Physics and Chemistry and also a course on Engineering Capstone Design. 


\title{
Development of a Team Interaction Observation Protocol and a Self-Efficacy Survey Using Social Cognitive Theory as a Framework
}

\begin{abstract}
In this paper, we present the development of two instruments designed to determine what student team interactions relate to self-efficacy and achievement. The social-cognitive theory constitutes the theoretical framework for the development of the instruments. Seven first-year engineering student teams participated in this study. Students took the self-efficacy survey and were video and audio-recorded during a semester. The first instrument created was a survey that measures engineering self-efficacy. Construct validity of this survey was established by correlating it with students' achievement scores. The internal consistency of the self-efficacy survey is 0.9. The content validity of both instruments was established by a comprehensive literature review and feedback from a panel of experts. The second instrument is an observation protocol designed to capture team oral discourses that occur when solving engineering design problems. Thirty-five discourse moves were established through an iterative process of code development and refinement. These moves were grouped under six discourse categories: task-oriented, responseoriented, learning-oriented, support-oriented, challenge-oriented, and disruptive. The results show that achievement and gain in self-efficacy are significantly correlated. There is also a positive correlation between support-orientated discourse and post self-efficacy scores. Negative correlations are observed between disruptive discourse behaviors and post self-efficacy scores. Discussion includes recommendations for engineering educators on how to help teams build supportive environments and what to look for when evaluating student team interactions.
\end{abstract}

\section{Introduction}

Teamwork is a common practice in engineering. Likewise, engaging students to work in collaborative teams to solve design problems is a common practice in engineering schools. A close examination of the team interactions of first-year engineering students was the main focus of this study. Designing an observation protocol to assess complex team dynamics would help with future research in engineering education aiming to study team processes. Using a mixedmethods approach, we identified team discourse characteristics that were correlated with student self-efficacy and achievement.

In the literature, team processes have been studied using diverse methods and tools such as peer evaluation surveys ${ }^{1}$ and verbal protocols ${ }^{20,22}$. Our study builds on these previous studies and contributes to teaching and research in engineering education in two ways: Firstly, it combines the survey, observation, and discourse analysis methods to establish a valid and reliable understanding of student team interactions. Secondly, the data for this study, collected through video and audio recordings, were obtained in a real first-year engineering classroom setting allowing us with an authentic view of student dynamics. The instruments designed in this study can be used for both research and instructional purposes.

From a research perspective, the team observation protocol can be used to explore a key variable in team settings: communication. Before investigating diverse learning processes that occur in 
teams (e.g., team design, problem solving, creativity), it is necessary to understand the communication variable that may support or hinder student performance. From an instructional perspective, these instruments can be used as part of intervention activities to support student team communication.

\section{Teamwork and Cooperative Learning}

The ABET criterion 3d requires engineering programs to demonstrate that their students have "an ability to function on multidisciplinary teams." (ABET, 2007) ${ }^{2}$. Thus, most programs use teaming as a mechanism to achieve this outcome. While the innovation in transforming classroom settings and curriculum to support collaborative learning is a progressing area, the use of social interactions in supporting learning is not a new thought. One of the historical movements in education that led to the investigation of group processes in the classroom relies on Dewey's work and philosophy on social learning and democratic living in the classroom ${ }^{3}$. Since then research focused on teaching and learning in collaborative contexts. One of the most referenced researchers in this area, Johnson, Johnson, and $\mathrm{Smith}^{4}$, describe basic elements of cooperative learning under five categories: having clearly perceived positive goal interdependence, giving students opportunities for frequent face-to-face interactions, establishing a clearly perceived individual accountability, having students frequently use teamwork skills, and giving students opportunities for regular group processing.

While cooperative research leads to positive outcomes when applied appropriately ${ }^{5}$, there is also a growing body of research showing that working in groups does not always lead to learning for $\mathrm{all}^{6}$. These studies report social capital issues that limit students' participation because of social factors $^{7,8}$. Considering the significant role of social interactions and environment in affecting student achievement, social cognitive theory is appropriate to explore the role of social interactions on student learning. In this study, we are interested in finding out how social interactions relate to achievement and self-efficacy in the context of engineering.

\section{Theoretical Framework: Social Cognitive Theory}

Social cognitive theory constitutes the theoretical framework for the development of both instruments (self-efficacy survey and the team interaction observation protocol) with the assertion that much human learning occurs in a social environment ${ }^{17}$. Social cognitive theory defines people as the producers as well as the products of their social environments. Therefore, using social cognitive theory to analyze student team interactions is deemed appropriate.

The self-efficacy theory, which was based on the social cognitive theory, is used for the design of the self-efficacy instrument. Self-efficacy theory entails both social and cognitive factors as critical components of learning. Bandura defines learning as an emergent result of a dynamic relationship between human behavior, environment, and human agent ${ }^{9}$. He introduced the selfefficacy theory in 1977, describing self-belief as an important factor in learning ${ }^{10,11}$. Selfefficacy beliefs translate perceptions of the environment and individual characteristics into behavior. For example, if a student with low self-efficacy joins a group; his or her initial perception of the group interactions would affect his or her initial behavior. Relatively, student's 
existence in the group would affect the group interactions. Self-efficacy beliefs are powerful predictors of behavior because they work as a cognitive and motivational drive that regulates human behavior.

The theory includes the description of four sources of self-efficacy: enactive mastery experience, vicarious experience, verbal or social persuasion, and physiological and affective reaction. These factors can support or hinder one's self-efficacy at various levels depending on the nature of the task. In this study, our focus will be on the role of verbal persuasion and mastery experiences. More specifically, we explore the verbal persuasions students exchange during team discussions and how these persuasions relate to their self-efficacy and achievement in class. Although verbal persuasions is only one of the four sources of self-efficacy, previous research (e.g. She, 1999 ${ }^{7}$ ) shows that social persuasion is a powerful factor in predicting self-efficacy in a team context. Furthermore, studies show that during small group discussions and interactions in science and engineering classrooms, negative social persuasions are frequently exchanged among the students ${ }^{7}$.

\section{The Relationship between Self-Efficacy and Achievement}

Self-efficacy is a strong predictor of educational achievement and cognitive learning ${ }^{12}$. While, the studies on engineering self-efficacy have generally focused on its relationship with student retention, the relationship between engineering self-efficacy and achievement has also been studied. Hutchison, Follman, Sumpter, and Bodner (2006) ${ }^{13}$ asked first-year engineering students to list factors affecting their self-confidence in their ability to succeed in their engineering classes. Their research showed that understanding of the course material was the most frequently stated factor affecting the students' self-efficacy. The relationship between self-efficacy and achievement has also been studied in mathematics ${ }^{14,15}$ and writing ${ }^{16}$. For example, Pajares and Miller (1994) ${ }^{14}$ studied self-efficacy in the context of mathematical problem solving. They found that math self-efficacy was the most powerful predictor of math problem solving compared to other predictors including prior mathematics experience. Schunk and Swartz (1993) ${ }^{17}$ studied the relationship between writing self-efficacy and writing skills of fifth grade students. They found a strong correlation between self-efficacy, writing skills and strategy use. Students that received specific progress feedback performed better than the control group that received only general feedback. One of our research goals is to explore if such a relationship exists in the context of engineering.

\section{Research Questions}

The main goal of this study is to describe the characteristics of team interactions that relate to achievement and self-efficacy. However, before investigating these correlations, we established the reliability and the validity of the instruments we developed. We investigated three research questions:

1. Is there a correlation between the self-efficacy scores, measured by the instrument designed for this study, and student achievement?

2. What type of team interactions correlate with self-efficacy? 
3. What type of team interactions correlate with student achievement?

We should note that this is not an intervention study. The main goal of this study is to closely observe and understand student team interactions. With the instruments we develop, our future research goal will be to develop interventions that can be tested for effectiveness.

\section{Research Methods}

\section{Class Context and Sample}

This study took place in a first-year introductory design course offered at a newly developed interdisciplinary program that has a focus on team-based design projects. A team of seasoned faculty designed and taught the course. In this class, teams of students engaged in design activities to solve open-ended problems. This environment was an appropriate context for our study because it enabled authentic student discourse in a real classroom where students had abundant opportunities to talk in teams. We followed the teams of students throughout a semester.

Twenty-four students participated in this study. Teams were composed of three or four students. All of the students took the self-efficacy surveys at the beginning and at the end of the Spring 2007 semester. All teams were video and audio-recorded during the semester. However, the communication coding data is based on six out of seven teams and twenty-two students because limited data was collected from one of the teams due to student absences and instrument malfunctioning.

\section{Determination of Student Achievement}

Instructors of the course used a detailed and rigorous evaluation method to assess student learning. Their evaluations of the student achievement were based on multiple forms of assessments: individual oral exams, individual written exams, team presentations, and team reports. We are confident that these data on students' cumulative grades in this course are valid and reliable representations of students' achievement. Students' achievement scores on their course assignments were used after obtaining permission from the students to access their grades.

\section{Establishing the Validity and Reliability of the Self-Efficacy Instruments}

Pajares $(1996)^{18}$ argues that self-efficacy measures should be designed to closely address the performance that students will be asked to perform. In addition, self-efficacy measures should take the context where the learning occurs into consideration. Bandura $(1997)^{10}$ suggests strict adherence to both content and context specificity in self-efficacy for valid results. Pajares, Hartley, and Valiante (2001) ${ }^{19}$ also suggest using a scale of 0-100 when measuring self-efficacy. They compared a writing self-efficacy assessment that is administered using 0-100 scale and 1-6 
Likert scale and found that the instrument that included a 0-100 scale resulted in greater discrimination and higher reliability than the instrument that included a Likert scale.

The self-efficacy instrument development principles, which are based on the content and context specificity of self-efficacy beliefs, limit the use of a single instrument for a wide number of studies. The development of a new self-efficacy survey will be required when the learning of a new skill or concept is to be researched. Consequently, the validity of these instruments would be measured based on their association to the learning task. Therefore, using self-efficacy scales with global items would not provide high correlations with achievement. The self-efficacy instrument we developed is a 10-point scale survey composed of sixteen questions (See Appendix A). The content validity of this instrument was established by aligning the survey items with the objectives of the class where we conducted our study. We met with the course instructors and discussed the instrument to check if the self-efficacy instrument met the course objectives and the expectations of the course instructors. Table 1 shows the item blueprint where the course objectives are listed on the left column and the number of items that matched with these objectives are listed on the far left column. The internal consistency and split-half reliability of the self-efficacy survey were found to be 0.9 . Additional construct validity of this survey was established by correlating it with students' achievement scores. The strong correlation between student achievement and post self-efficacy scores $(\mathrm{R}=0.45, p<0.05)$ shows the instrument's alignment with the theoretical framework that the instruments is designed upon.

Table 1. Objectives of the Introduction to Engineering Design Course

\begin{tabular}{|c|c|c|}
\hline $\begin{array}{l}\text { Course Objectives } \\
\text { Students will be able to ... }\end{array}$ & Category & Number of Items \& Item Numbers \\
\hline $\begin{array}{l}\text { 1. communicate and use } \\
\text { engineering design process }\end{array}$ & Design & Item \#1 and item \#2 \\
\hline $\begin{array}{l}\text { 2. } \begin{array}{l}\text { create engineering models } \\
\text { (purposeful representations) }\end{array} \\
\text { 3. introduced to CADD as a tool } \\
\text { for capturing and documenting } \\
\text { design }\end{array}$ & $\begin{array}{l}\text { Engineering } \\
\text { Practice }\end{array}$ & Items \#3 and item\# 4 \\
\hline $\begin{array}{l}\text { 4. communicate through } \\
\text { engineering reports and team } \\
\text { presentations. } \\
\text { 5. organize and manage projects, } \\
\text { and work effectively in teams }\end{array}$ & $\begin{array}{l}\text { Communication } \\
\text { \& Teaming }\end{array}$ & Items \# 5, 6, 7, and 8 \\
\hline $\begin{array}{l}\text { 6. understand fundamental force } \\
\text { concepts }\end{array}$ & $\begin{array}{l}\text { Technical } \\
\text { Competence }\end{array}$ & Items \# 9,10,11,12,13,14,15, and 16 \\
\hline
\end{tabular}

Establishing the Validity and Reliability of the Team Interaction Observation Protocol 
Different team interaction coding protocols have been established to study team learning and communication processes. For example, Kaartinen \& Kumpulainen $(2002)^{20}$ developed a protocol when studying collaborative inquiry methods used by students learning science. They focused on four areas: discourse moves (e.g. initiating), logical processes (e.g. propose a cause), nature of explanation (formal explanation), and cognitive strategies (construction of question). Sizmur \& Osborn $(1997)^{21}$ used a different coding method to study group concept mapping processes in science. Other researchers studied design problem solving processes of expert engineers $^{22}$. Verbal protocol analysis methods have also been used in the context of engineering design when studying teams ${ }^{23}$.

Our first step in designing the team interaction observation protocol was reviewing similar team instruments developed and used by other scholars. We explained these instruments in above. Consequently, the content validity of this instrument was established by using this literature review and feedback from a panel of experts who reviewed the coding scheme. The initial version of the coding scheme was developed based on the coding schemes used in previous research. The initial form of the observation protocol, designed to capture team oral discourse, included twenty-eight discourse moves under eight discourse categories: leading, sharing, questioning, clarifying, defending, supporting, discouraging, and disrupting.

The second phase involved an iterative process of code development and refinement. Following the recommendations of Miles and Huberman (1994) ${ }^{24}$, one researcher coded samples of discourses from each team and identified whether the initial codes were appropriate and if new categories were needed. The number of discourse moves in the team interaction observation protocol were then increased to thirty-five discourse moves that were grouped under six discourse categories: task-oriented, response-oriented, learning-oriented, support-oriented, challenge-oriented, and disruptive. The coding book is included in Attachment B. Table 2 shows a short episode from one of the teams. As seen in this table, both the students who engaged in the action (action by) and the student towards whom the action was directed (action towards) were recorded during coding.

Table 2. Sample Coding

\begin{tabular}{|l|l|c|c|c|}
\hline $\begin{array}{l}\text { Student Code } \\
\text { Name }\end{array}$ & Discourse & $\begin{array}{c}\text { Action } \\
\text { By }\end{array}$ & $\begin{array}{c}\text { Discourse } \\
\text { Move }\end{array}$ & $\begin{array}{c}\text { Action } \\
\text { Towards }\end{array}$ \\
\hline A2: Alex & $\begin{array}{l}\text { I think one of our priorities should be distance } \\
\text { from the building when you lower it down. } \\
\text { Like having a little hang up away from the } \\
\text { building or whatever, before it comes down }\end{array}$ & A2 & IDE & EXP \\
\hline A3: Arnold & And make sure it's not wood or it will burn... & A3 & ADD & A2 \\
\hline A4: Azra & $\begin{array}{l}\text { (interrupts) distance of what? } \\
\text { Distance of our device? }\end{array}$ & $\begin{array}{c}\text { A4 } \\
\text { A4 }\end{array}$ & $\begin{array}{c}\text { INFQ } \\
\text { INT }\end{array}$ & $\begin{array}{c}\text { A2 } \\
\text { A3 }\end{array}$ \\
\hline
\end{tabular}

The inter-rater reliability was established between two coders who discussed their coding and reached an agreement. The intra-rater reliability of the team interaction observation protocol was 
also conducted where the principal researcher coded the data twice with an interval of several week and compared the alignment of these codings.

\section{Data Analysis Methods}

A mixed-methods approach was used for data analysis combining both qualitative and quantitative methods. These two methods complemented each other where the qualitative data analysis methods addressed the question of what types of team discourses students engaged in and the quantitative methods helped us reveal any significant correlations between student team discourse characteristics, self-efficacy, and achievement.

The qualitative methods included discourse analysis. First, all student discourses were transcribed as shown in Table 2. Next, using the communication coding scheme, the verbal exchanges between the students who are working in the same team are coded.

The quantitative methods included the computation of Pearson product-moment correlation coefficients. This correlation analysis was used to analyze the degree of relationship between normalized gain in engineering self-efficacy, social persuasion, and academic performance. Gain in engineering self-efficacy was computed using standard gain score calculations: gain= (postpre)/(max-pre). In this formula pre and post represent self-efficacy scores at the beginning and at the end of the semester and max represent the maximum possible score on the self-efficacy measure.

\section{Results}

After competing the coding of the discourses by the student teams, we explored the answers to our research questions. We conducted a two-tailed test using Pearson correlation analysis. We found correlations among the categories of team interaction characteristics as shown in Table 3. This table shows that there was a strong correlation between task-oriented student behavior and response-oriented student behavior. Furthermore, even a stronger correlation existed between support-oriented behavior and task-orientation and response-oriented behaviors.

Table 3. Correlations between Achievement and Team interaction Behaviors

\begin{tabular}{lccccc}
\hline & $\begin{array}{c}\text { Response- } \\
\text { Oriented }\end{array}$ & $\begin{array}{c}\text { Learning- } \\
\text { Oriented }\end{array}$ & $\begin{array}{c}\text { Support- Challenge } \\
\text { Oriented }\end{array}$ & -Oriented \\
\hline Task-Oriented & $.435^{*}$ & .409 & $.534^{* *}$ & .189 & -.110 \\
Response-Oriented & & .243 & $.566^{* *}$ & .593 & -.220 \\
Learning-Oriented & & & .383 & .114 & -.183 \\
Support-Oriented & & & .196 & $-.417^{*}$ \\
Challenge-Oriented & & & & .363 \\
\hline * Correlation is significant at the 0.05 level (2-tailed). ** Correlation is significant at the 0.01 level (2-tailed).
\end{tabular}

The discourse category that was the most commonly seen in the data was response-oriented behavior (See Figure 1). In this sample, support oriented and learning-oriented behaviors were high compared to the disruptive, challenge-oriented, and goal-oriented behaviors. 


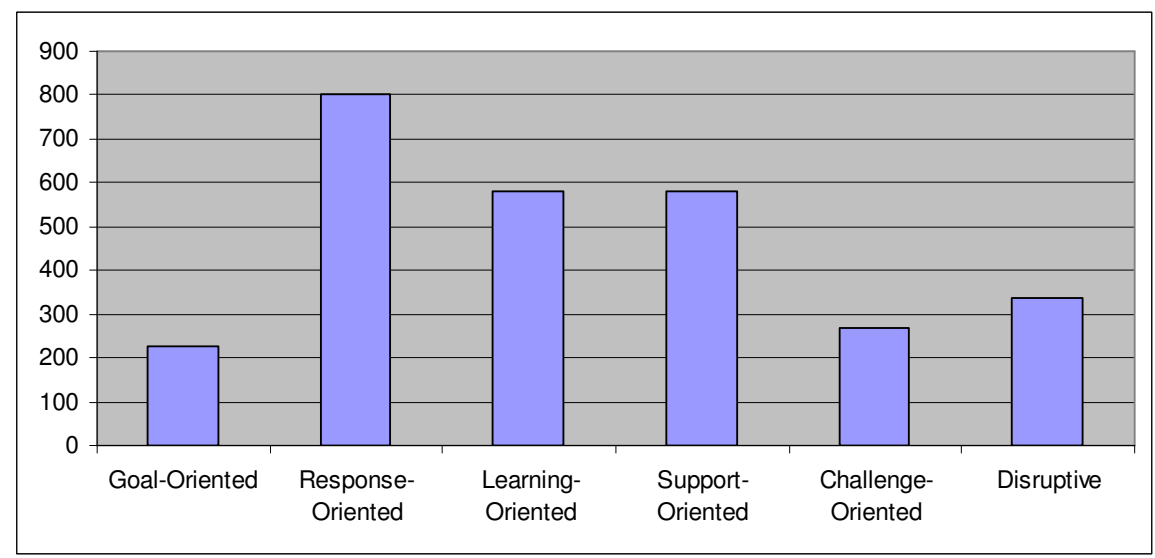

Figure 1. The Frequency of the Discourse Categories used by the Students

The first question we explored was the correlation between the self-efficacy scores, measured by the instrument designed for this study, and student achievement. As shown in Table 4, we found a strong correlation between student achievement and post self-efficacy scores $(\mathrm{R}=0.46, \mathrm{p}<0.05)$ and gain in their self-efficacy $(\mathrm{R}=.55, \mathrm{p}<.01)$. However, there were no significant correlations between student's initial self-efficacy scores and their course achievement $(R=-0.1, p=0.65)$.

With the second question, we conducted correlation analysis to find out the type of team interactions that correlated with self-efficacy. Final self-efficacy was negatively correlated with disruptive and discouraging behaviors initiated during team meetings $(\mathrm{R}=-0.48, \mathrm{p}<0.05)$. This finding could indicate that the students who engaged in off-task behavior were more likely to establish low self-efficacy by the end of the semester. It could also mean that students with low self-efficacy were less motivated and therefore engage in more disruptive behaviors than the students with higher self-efficacy.

Table 4. Correlations between Self-Efficacy Scores and Discourse Categories

\begin{tabular}{lccc}
\hline $\begin{array}{l}\mathrm{N}=22 \text { Engagement in } \\
\text { actions that are ... }\end{array}$ & Pre Self-Efficacy & Post Self-Efficacy & Gain in Self-Efficacy \\
\hline Task-Oriented & .11 & .30 & .31 \\
Response-Oriented & $.46^{*}$ & .40 & .04 \\
Learning-Oriented & .18 & -.08 & -.13 \\
Support-Oriented & .23 & $.43^{*}$ & .32 \\
Challenge-Oriented & .20 & -.05 & -.13 \\
Disruptive & -.04 & $-.48^{*}$ & -.28 \\
\hline$*$ Correlation is significant at the 0.05 level (2-tailed). ** Correlation is significant at the 0.01 level (2-tailed).
\end{tabular}

Neither being challenged by peers nor receiving negative feedback revealed significant correlations with student self-efficacy. In addition, no correlations between the team discourse characteristics and achievement were found. These findings suggest that while positive team discourse can support self-efficacy, the effect of such behaviors on student achievement was indirect. 
Finally, our third research question was regarding the type of team interactions that were correlated with student achievement. We did not find any direct correlations between any of the team interaction behaviors and student achievement.

\section{Summary and Implications for Teaching and Recommendations}

Our main finding was that there is a correlation between student achievement and gain selfefficacy. However, this correlation did not exist in the pre self-efficacy survey. This suggests that throughout the course of the semester, students were able to build higher self-efficacies through their mastery experiences and established more accurate perceptions of their own knowledge and skills.

There was a positive correlation between support-orientated discourse and post self-efficacy scores. Since this was a correlation study, we can not make claims regarding the direction of the relationships. However, it is possible that engaging in positive discourse is an indication of high self-efficacy. It is also possible that self-efficacy can be supported by engaging in positive and supportive discourse. Negative correlations were observed between disruptive discourse behaviors and post self-efficacy scores. This finding suggests that students with low self-efficacy are more likely to engage in off-task and negative behaviors. This could be due to their lack of motivation, which is a construct highly related to self-efficacy. Another explanation is that the students who have a tendency to engage in negative behavior are less likely to develop high selfefficacy.

Our findings suggest that students need to engage in more support-oriented discourses. We recommend that when using team-based instruction, students should be taught how to engage in supportive discourse. Time can be allocated for intervention activities where the members of student teams identify each other's strengths. There should also be an emphasis on helping students define learning goals. Students can be asked to share their learning goals with their team members and discuss ways their team can support them. This could reduce disruptive behaviors and help motivate all students.

Through this study, we developed a team interaction observation protocol that can be used to help students recognize the strengths and weaknesses in their team interactions. Our goal is to improve and modify the coding scheme so that it can be used in the classroom as an instructional tool. We will also study more teams and conduct a factor analysis of the coding instrument. 


\section{Bibliography}

${ }^{1}$ Ohland, M., Pomeranz, H.R., and Feinstein, H.W. (2006). The comprehensive assessment of team member effectiveness: A new peer evaluation instrument. Paper presented at the annual meeting of American Society for Engineering Education.

${ }^{2}$ http://www.abet.org/forms.shtml\#For_Engineering_Programs_Only

${ }^{3}$ Dewey, J. (1938). Experience and Education. New York: Collier/Macmillan

${ }^{4}$ Johnson, David W., Johnson, Roger T., and Smith, Karl A. (1991). Cooperative learning: Increasing college faculty instructional productivity. ASHE-ERIC Report on Higher Education. Washington, DC: The George Washington University.

5 Johnson, D., Johnson, R.\& Holubec, E. (1998). Cooperation in the classroom. Boston: Allyn and Bacon.

${ }^{6}$ Taconis, R., Ferguson-Hessler M.G.M., \& Broekkamp, H. (2001). Teaching Science Problem Solving: An Overview of Experimental Work. Journal of Research in Science Teaching, 38(4), 442-468.

${ }^{7}$ She, H. (1999). Students' knowledge construction in small groups in the seventh grade biology laboratory: Verbal communication and physical engagement. International Journal of Science Education, 21(10), 1051-1066.

${ }^{8}$ Southerland, S., Kittleson, J., Settlage, J., and Lanier, K. (2005). Individual and group meaning-making in an urban third grade classroom: red fog, cold cans, and seeping vapor. Journal of Research in Science Teaching, 42(9), 1032-1061.

${ }^{9}$ Bandura (2001). Social Cognitive Theory: An Agentic Perspective, Annual. Reviews of Psychology. 52, 1-26.

${ }^{10}$ Bandura, A. (1997). Self-Efficacy: The Exercise of Control. New York, NY: W.H. Freeman and Company.

${ }^{11}$ Pajares, F. ( 2007) viewed on January 2, 2007. http://www.des.emory.edu/mfp/eff.html

${ }^{12}$ Lent, R.W., Lopez, F.G., and Bieschke, K.J. (1991). Mathematics self-efficacy: Sources and relations to sciencebased career choice. Journal of Counseling Psychology, 38, 424-430.

${ }^{13}$ Hutchinson, M.A., D.K. Follman, M. Sumpter, and G.M. Bodner (2006). Factors Influencing the Self-Efficacy Beliefs of First-Year Engineering Students. Journal of Engineering Education, 95(1), 39-47.

${ }^{14}$ Pajares, F. and Miller, M. D. (1994). Role of Self-Efficacy and Self-Concept Beliefs in Mathematical Problem Solving: A Path Analysis. Journal of Educational Psychology, 86(2), 193-203.

${ }^{15}$ Lent, R.W., Lopez, F.G., and Bieschke, K.J. (1991). Mathematics self-efficacy: Sources and relations to sciencebased career choice. Journal of Counseling Psychology, 38, 424-430.

${ }^{16}$ McCarthy, P., Meier, S., \& Rinderer, R. (1985). Self-efficacy and writing. College Composition and Communication, 36, 465-471.

${ }^{17}$ Schunk, D. H., \& Swartz, C. W. (1993). Goals and progress feedback: Effects on self-efficacy and writing achievement. Contemporary Educational Psychology, 18, 337-354.

${ }^{18}$ Pajares, F. (1996). Self-Efficacy Beliefs in Academic Settings. Review of Educational Research, 66(4), 543-578.

${ }^{19}$ Pajares, F.,Hartley, J., and Valiante, G. (2001.) Response Format in Writing Self-Efficacy Assessment: Greater Discrimination Increases Prediction. Measurement and Evaluation in Counseling and Development, 33, 214221.

${ }^{20}$ Kaartinen, S., \& Kumpulainen, K. (2002). Collaborative inquiry and the construction of explanations in the learning of science. Learning and Instruction, 12(2), 189-212.

${ }^{21}$ Sizmur, S. \& Osborne, J. (1997). Learning processes and collaborative concept mapping. International Journal of Science Education, 19(10), 1117-1135.

${ }^{22}$ Cross, N., Christiaans, H., \& Dorst, K. (1996). Analysing design activity. Chichester: Wiley.

${ }^{23}$ Brereton, M.F., Cannon, M.C., Mabogunje, A., Leifer, L, "Collaboration in Design Teams: How Social Interaction Shapes the Product," in Analyzing Design Activity, K. Dorst, H. Christiaans, H. Cross, (Editors). Wiley, Chichester, UK, 1996.

${ }^{24}$ Miles, M. B. and Huberman, A.M. (1994). Qualitative Data Analysis. Thousand Oaks, CA: Sage Publication 


\section{Appendix A}

\section{ENGINEERING SELF-EFFICACY}

DIRECTIONS: On the items below, please rate your confidence that you can perform the given task. Please rate your degree of confidence using the scale provided below by recording a number from 0 to 100 in each blank space.

Cannot do

$0 \% \quad 10 \%$
Moderately certain can do

$20 \% \quad 30 \%$
$40 \% \quad 50 \% \quad 60 \% \quad 70 \%$
Certain can do

$80 \%$

\begin{tabular}{|c|c|}
\hline Please indicate how confident you are in your ability to... & $(0-100 \%)$ \\
\hline 1. explain the steps of the engineering design process. & \\
\hline 2. use the steps of the engineering design process to solve an engineering design problem. & \\
\hline 3. build a prototype model using the appropriate cutting, joining, and shaping tools. & \\
\hline 4. use a CADD (computer-aided drafting and design) software to document a design concept. & \\
\hline 5. write a formal project report for an engineering design project. & \\
\hline 6. orally present results of a design project to an audience. & \\
\hline 7. have effective communication with your engineering design team members. & \\
\hline 8. manage time and tasks effectively during a team design project. & \\
\hline 9. conduct experiments to collect scientific data. & \\
\hline 10. write a mathematical model (speed, acceleration, etc.) of a falling object & \\
\hline $\begin{array}{l}\text { 11. use a graphical model (velocity-time or acceleration-time graphs) to predict the performance of } \\
\text { a moving object. }\end{array}$ & \\
\hline 12. explain how non-conservative forces (friction and air resistance) affect energy conservation. & \\
\hline $\begin{array}{l}\text { 13. explain how Newton's laws apply to objects moving in two dimensions with a projectile } \\
\text { motion. }\end{array}$ & \\
\hline 14. explain the motion of an object on a frictionless circular path. & \\
\hline 15. use Newton's laws to solve an engineering design problem involving a falling object. & \\
\hline $\begin{array}{l}\text { 16. use energy conservation principles to solve an engineering design problem involving a falling } \\
\text { object. }\end{array}$ & \\
\hline
\end{tabular}




\section{Appendix B}

Team Interaction Observation Protocol Coding Scheme

\begin{tabular}{|c|c|c|c|c|c|}
\hline & & Code & $\begin{array}{l}\text { Discourse } \\
\text { Move }\end{array}$ & Description & Examples of Utterances \\
\hline \multirow{6}{*}{ 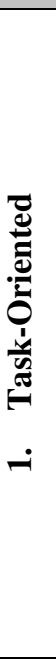 } & 1. & TAS & $T A S K$ & $\begin{array}{l}\text { Repeating the task and requirements of the } \\
\text { assignment to establish a direction. }\end{array}$ & $\begin{array}{l}\text { We are not evaluating } \\
\text { yet, just brainstorming. }\end{array}$ \\
\hline & 2. & DIR & DIRECT & $\begin{array}{l}\text { Giving commands and directions. Asking } \\
\text { someone to do something. }\end{array}$ & $\begin{array}{l}\text { Chris, move the } \\
\text { thermometer. } \\
\text { Multiply it by } 10 \text {. }\end{array}$ \\
\hline & 3. & FOC & FOCUS & $\begin{array}{l}\text { Bringing team back to focus (usually after an } \\
\text { off-task discussion). }\end{array}$ & $\begin{array}{l}\text { Let's identify the } \\
\text { constraints now. }\end{array}$ \\
\hline & 4. & VOL & VOLUNTEER & $\begin{array}{l}\text { Volunteering for a job. Taking the } \\
\text { responsibility of a task or assignment. }\end{array}$ & I can buy the shaft. \\
\hline & 5. & SUM & SUMMARIZE & $\begin{array}{l}\text { Summarizing what is discussed before } \\
\text { moving on the next task. Stating a group } \\
\text { decision. }\end{array}$ & $\begin{array}{l}\text { So, we have different } \\
\text { molds and different } \\
\text { temperatures of the gel. } \\
\text { Ok, then, we are } \\
\text { building a bridge. }\end{array}$ \\
\hline & 6. & TAQ & $\begin{array}{l}\text { TASK } \\
\text { QUESTION }\end{array}$ & Checking if tasks are done. & $\begin{array}{l}\text { Did you write your } \\
\text { sections? }\end{array}$ \\
\hline \multirow{5}{*}{ 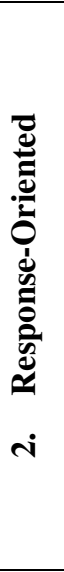 } & 7. & IDE & $I D E A$ & $\begin{array}{l}\text { Introducing and sharing new ideas and } \\
\text { suggestions. }\end{array}$ & I have stop sign. \\
\hline & 8. & FAC & FACTS & $\begin{array}{l}\text { Sharing scientifically correct information, } \\
\text { data, and scientific facts with team members. }\end{array}$ & $\begin{array}{l}\text { One "g" is } 32.2 \text { feet per } \\
\text { second squared. }\end{array}$ \\
\hline & 9. & UNC & $\begin{array}{l}\text { UNCERTAINT } \\
Y\end{array}$ & $\begin{array}{l}\text { An answer that shows uncertainty or lack of } \\
\text { knowledge. }\end{array}$ & I don't know \\
\hline & 10. & ANS & ANSWERING & $\begin{array}{l}\text { Answering team members' questions by } \\
\text { clarifying issues and providing examples. }\end{array}$ & $\begin{array}{l}\text { You identify a weight } \\
\text { for each criterion and } \\
\text { multiply it by the score } \\
\text { we have given. }\end{array}$ \\
\hline & 11. & EXP & EXPANDING & $\begin{array}{l}\text { Expanding own contribution and providing } \\
\text { additional information. Elaborating on a topic } \\
\text { that is somewhat understood. }\end{array}$ & $\square$ \\
\hline \multirow{4}{*}{ 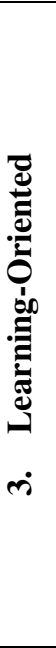 } & 12. & REF & REFLECTING & $\begin{array}{l}\text { Reflecting on own understanding. Clarifying } \\
\text { own thoughts during the process of orally } \\
\text { sharing ideas with the team. Recognizing } \\
\text { own misunderstanding. Reformulating own } \\
\text { idea. }\end{array}$ & $\begin{array}{l}\text { But then I was like that } \\
\text { would be like ice cubes } \\
\text { and water expand } \\
\text { when you freeze them. } \\
\text { I am having difficulty } \\
\text { because I am used to } \\
\text { learning by trial and } \\
\text { error. }\end{array}$ \\
\hline & 13. & INFQ & $\begin{array}{l}\text { INFO } \\
\text { QUESTION }\end{array}$ & Asking for factual information. & Which page is it? \\
\hline & 14. & CLQ & $\begin{array}{l}\text { CLARIFICATI } \\
\text { ON QUESTION }\end{array}$ & $\begin{array}{l}\text { Requesting explanation \& clarification. } \\
\text { Asking for rationale (intention is } \\
\text { understanding). }\end{array}$ & $\begin{array}{l}\text { What do you mean by } \\
\text {...? } \\
\text { Why do you think so? }\end{array}$ \\
\hline & 15. & INPQ & $\begin{array}{l}\text { INPUT } \\
\text { QUESTION }\end{array}$ & $\begin{array}{l}\text { Asking for peer's input, opinions, \& ideas. } \\
\text { Asking for a vote (intention is group } \\
\text { thinking). }\end{array}$ & $\begin{array}{l}\text { What else can we add? } \\
\text { How about exploring } \\
\text { this? }\end{array}$ \\
\hline
\end{tabular}




\begin{tabular}{|c|c|c|c|c|c|}
\hline & 16. APQ & $\begin{array}{l}\text { APPROVAL } \\
\text { QUESTION }\end{array}$ & $\begin{array}{l}\text { Weak idea or proposal that shows some } \\
\text { hesitation or seeks approval. }\end{array}$ & 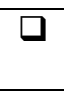 & $\begin{array}{l}\text { We are using the } \\
\text { metric system, right? }\end{array}$ \\
\hline & 17. RET & RETRACTING & $\begin{array}{l}\text { Backing down on an idea usually in the face } \\
\text { of a challenge or disagreement by a peer. }\end{array}$ & 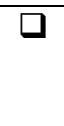 & $\begin{array}{l}\text { Really? Ok, then. We } \\
\text { can do that (your } \\
\text { suggestion). }\end{array}$ \\
\hline \multirow{7}{*}{ 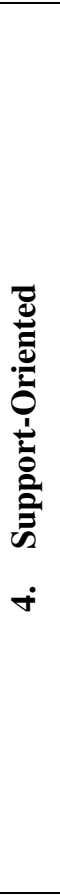 } & 18. AGR & AGREE & $\begin{array}{l}\text { Brief expression of acceptance or agreement } \\
\text { with the team members' suggestions. } \\
\text { Indicates understanding and is a sign of } \\
\text { listening. }\end{array}$ & $\square$ & Yeah, ok. \\
\hline & 19. COM & COMPLETING & $\begin{array}{l}\text { Completing peer's explanation or sentence. } \\
\text { Can seem like an interruption but in a } \\
\text { complementing way. }\end{array}$ & $\square$ & .. \\
\hline & 20. SYN & $\begin{array}{l}\text { SYNCHRONIZI } \\
\text { NG }\end{array}$ & $\begin{array}{l}\text { Repeating a peer's comment. Re-stating } \\
\text { peer's comment or idea. Stating that he or she } \\
\text { was thinking the same. }\end{array}$ & $\square$ & $\begin{array}{l}\text { Yeah, I was also gonna } \\
\text { ask how much budget } \\
\text { we have. }\end{array}$ \\
\hline & 21. ADD & $A D D I N G$ & $\begin{array}{l}\text { Adding or elaborating on a peer's idea. } \\
\text { Rephrasing or extending on peer comments, } \\
\text { adding justification. }\end{array}$ & $\square$ & $\begin{array}{l}\text { That would also be the } \\
\text { cheapest option. }\end{array}$ \\
\hline & 22. PRA & PRAISE & $\begin{array}{l}\text { Acknowledging team members' contributions } \\
\text { to the project and praising their good or } \\
\text { interesting ideas. }\end{array}$ & $\square$ & That is a great idea. \\
\hline & 23. SUP & $\begin{array}{l}\text { SUPPORTING } \\
\text { PEER }\end{array}$ & $\begin{array}{l}\text { Protecting or defending a peer who is faced } \\
\text { with opposition by another person. Uses } \\
\text { evidence to support a peer's assertion. }\end{array}$ & 口 & $\begin{array}{l}\text { I agree with Chris, this } \\
\text { should not be an issue } \\
\text { if we heat the blade. }\end{array}$ \\
\hline & 24. PAR & $\begin{array}{l}\text { PARTIAL } \\
\text { SUPPORT }\end{array}$ & $\begin{array}{l}\text { Partial support despite disagreement (goal is } \\
\text { to have everyone's ideas incorporated) }\end{array}$ & $\square$ & $\begin{array}{l}\text { We won't set it as a } \\
\text { criteria but we will still } \\
\text { try to do it. }\end{array}$ \\
\hline \multirow{4}{*}{ 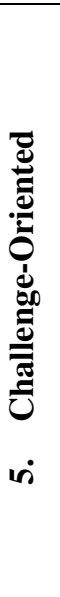 } & 25. DEF & $\begin{array}{l}\text { DEFENDING } \\
\text { OWN POINT }\end{array}$ & $\begin{array}{l}\text { When faced with opposition, defending own } \\
\text { ideas by disagreeing with the opposition, } \\
\text { providing justification, and further } \\
\text { explanation. Justifying own assertion with } \\
\text { evidence. }\end{array}$ & $\square$ & $\begin{array}{l}\text { I know. But if you've } \\
\text { ever been to west } \\
\text { campus, they have the } \\
\text { same thing there and it } \\
\text { works. }\end{array}$ \\
\hline & 26. ALT & ALTERNATIVE & $\begin{array}{l}\text { Raises an alternative to peer's idea by using } \\
\text { strong evidence and previous learning } \\
\text { experiences. }\end{array}$ & $\square$ & $\begin{array}{l}\text { Lab equipment is } \\
\text { expensive but it would } \\
\text { also be expensive to } \\
\text { move a lab. }\end{array}$ \\
\hline & СНА & CHALLENGE & Challenging a peer's assumptions. & $\square$ & $\begin{array}{l}\text { Doesn't it sound like } \\
\text { not caring for the } \\
\text { baby? }\end{array}$ \\
\hline & 27. DIS & DISAGREE & $\begin{array}{l}\text { Briefly rejecting or disagreeing with team } \\
\text { members' suggestions. }\end{array}$ & $\square$ & $\begin{array}{l}\text { No, you don't need } \\
\text { that. }\end{array}$ \\
\hline \multirow[t]{3}{*}{ 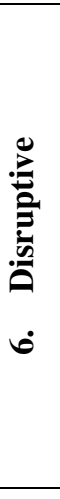 } & 28. NEG & NEGATIVE & $\begin{array}{l}\text { Negative Criticism: Rejection with overtones } \\
\text { of a personal attack or disparaging remarks. } \\
\text { Correcting mistakes in an offensive way. } \\
\text { Making sarcastic comments or using humor } \\
\text { in a negative way. }\end{array}$ & $\begin{array}{l}\square \\
\square \\
\square\end{array}$ & $\begin{array}{l}\text { That doesn't make any } \\
\text { sense. } \\
\text { Gardening is a } \\
\text { feminine thing. } \\
\text { Freezing a chocolate is } \\
\text { not allowed. Read the } \\
\text { handbook. }\end{array}$ \\
\hline & 29. INT & INTERRUPT & $\begin{array}{l}\text { Interrupting a team member's speech } \\
\text { abruptly and disrespectfully to reject his/her } \\
\text { idea. }\end{array}$ & $\square$ & \\
\hline & 30. IGN & IGNORING & $\begin{array}{l}\text { Ignoring team members' questions or } \\
\text { suggestions. Changing the topic. }\end{array}$ & $\square$ & $\begin{array}{l}\text { no response or } \\
\text { changing the subject) }\end{array}$ \\
\hline
\end{tabular}




\begin{tabular}{lllll}
\hline 31. OFF & OFFTASK & $\begin{array}{l}\text { Initiating off-task topics/discussions that are } \\
\text { not related to the assignment. }\end{array}$ & $\square$ I am hungry. \\
\hline 32. OFFP & $\begin{array}{l}\text { OFFTASK } \\
\text { PARTICIPANT }\end{array}$ & Participating in off task discussions. & $\square$ \\
\hline 33. PER & PERSONAL & $\begin{array}{l}\text { Sharing personal information such as } \\
\text { interests, values, and feelings. }\end{array}$ & $\begin{array}{l}\text { I don't break apart } \\
\text { things. } \\
\text { My father bought a } \\
\text { shock absorber last } \\
\text { week. }\end{array}$ \\
\hline 34. MIS & MISTAKE & $\begin{array}{l}\text { Interpreting the task incorrectly. Conveying } \\
\text { scientifically incorrect information, facts, } \\
\text { calculations, etc with team members. }\end{array}$ & $\square$ \\
\hline
\end{tabular}

